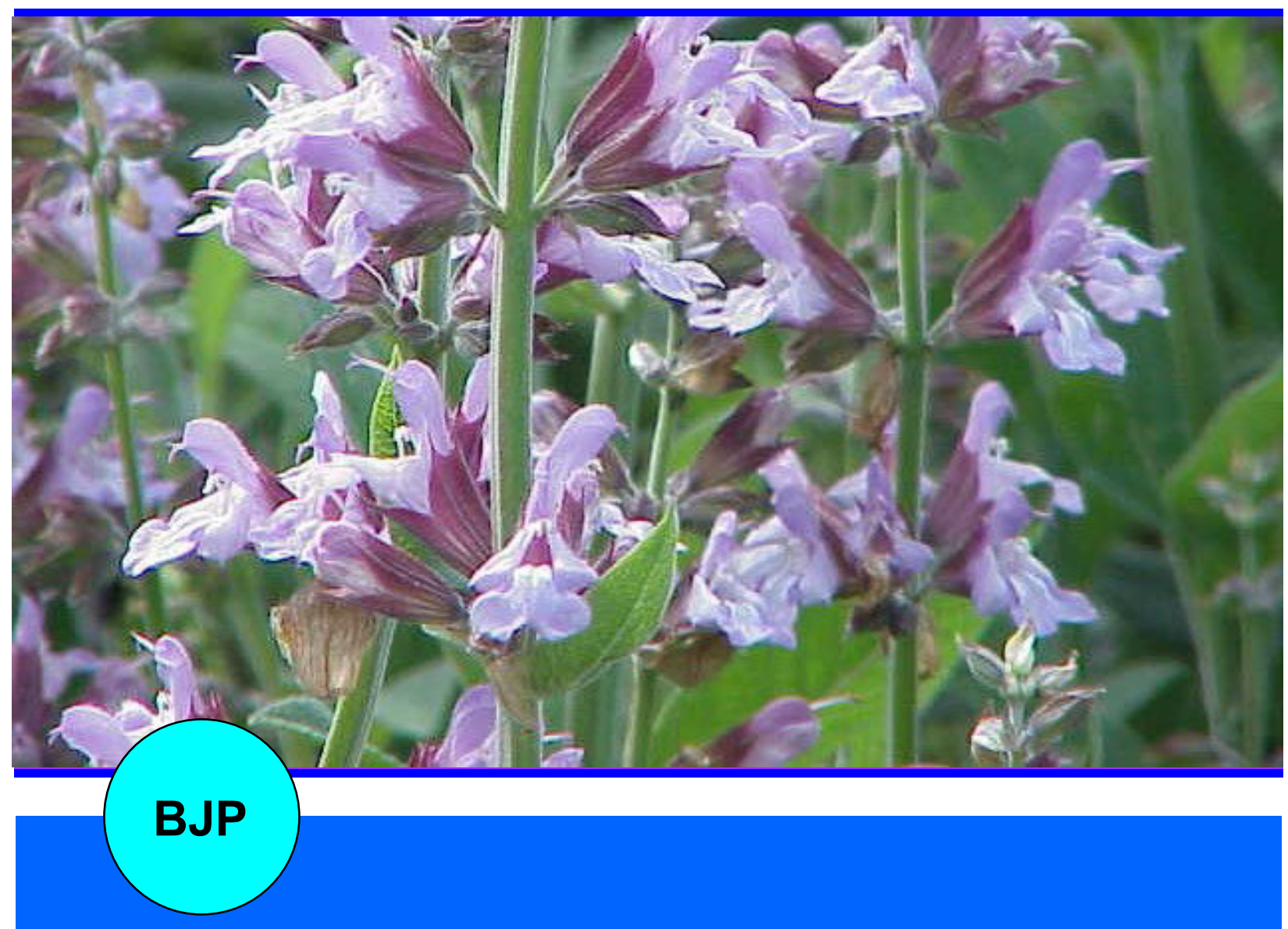

Bangladesh Journal of Pharmacology

Research Article

Antidiarrheal and antispasmodic activities of Salvia officinalis are mediated through activation of $\mathrm{K}^{+}$channels 


\title{
Antidiarrheal and antispasmodic activities of Salvia officinalis are mediated through activation of $\mathrm{K}^{+}$channels
}

\author{
Aslam Khan'1, Najeeb-ur-Rehman'1, Khalid M. AlKharfy² and Anwarul-Hassan Gilani,1,2 \\ ${ }^{1}$ Natural Products Research Division, Department of Biological and Biomedical Sciences, Aga Khan University \\ Medical College, Karachi 74800, Pakistan; ${ }^{2}$ Department of Clinical Pharmacy, College of Pharmacy, King Saud \\ University, Riyadh, Saudi Arabia.
}

\begin{tabular}{|c|c|}
\hline Article Info & \\
\hline Received: & 10 December 2011 \\
\hline Accepted: & 10 December 2011 \\
\hline Available Online: & 11 December 2011 \\
\hline DOI: $10.3329 /$ bjp.v & $6 \mathrm{i} 2.9156$ \\
\hline $\begin{array}{l}\text { Cite this article: } \\
\text { Khan A, Rehman } \\
\text { Gilani AH. Antid } \\
\text { spasmodic activitie } \\
\text { are mediated throu } \\
\text { channels. Banglad } \\
\text { 2011; 6: 111-116. }\end{array}$ & $\begin{array}{l}\text { N, AlKharfy KM, } \\
\text { liarrheal and anti- } \\
\text { es of Salvia officinalis } \\
\text { agh activation of } \mathrm{K}^{+} \\
\text {desh J Pharmacol. }\end{array}$ \\
\hline
\end{tabular}

\begin{abstract}
This study was conducted to provide pharmacological basis for the medicinal use of Salvia officinalis in diarrhea. The crude extract of S. officinalis was studied using the in vivo and in vitro assays. The crude extract inhibited castor oil-induced diarrhea in mice at the dose of 100 and $300 \mathrm{mg} / \mathrm{kg}$. In isolated rabbit jejunum, it caused a dose-dependent $(0.1-3 \mathrm{mg} / \mathrm{mL})$ relaxation of spontaneous as well as low $\mathrm{K}^{+}(25 \mathrm{mM})$ and high $\mathrm{K}^{+}(80 \mathrm{mM})$-induced contractions, being distinctly more potent on low $\mathrm{K}^{+}$. Pretreatment of tissue with 4-aminopyridine $(1 \mathrm{mM})$ almost completely blocked the inhibitory effect of crude extract on low $\mathrm{K}^{+}$. These results indicate that the crude extract of $S$. officinalis possesses antidiarrheal and antispasmodic activities mediated possibly through the dominant activation of voltage-dependent $\mathrm{K}^{+}$channels and this study provides sound pharmacological basis for its medicinal use in diarrhea and gut spasm.
\end{abstract}

\section{Introduction}

Salvia officinalis Linn. (family; Lamiaceae), commonly known as garden or red Sage, is a perennial hardy subshrub native to Mediterranean regions and is one of the most popular medicinal and culinary herbs used in the Arab world (Qnais et al., 2010). In traditional medicine systems, S. officinalis is used to treat diarrhea, colic, dyspepsia, constipation, asthma, bronchosis, catarrh, cough, dyspnea and depression (Duke, 2002). Sage is also used externally for inflammation of the mucous membranes of nose and throat (Fleming, 1998).

Phytochemical investigations revealed the presence of volatile oils (thujone, alpha-thujone and beta-thujone), 1, 8-cineole, camphor, borneol, isobutyl acetate, camphene, linalool, alpha- and beta-pinene, viridiflorol, alpha- and beta-caryophyllene (Fleming, 1998), salvianolic acid (Lu et al., 2001). In the caffeic acid derivatives, rosmarinic acid, chlorogenic acid include while in diterpenes, the main components are carnosolic acid, rosmanol and safficinolide. It also contains some flavonoids such as apigenin- and luteolin-7glucosides, and aglycones, while ursolic acid is the chief triterpenes constituents (Fleming, 1998).

The plant is well studied for its biological activities and is reported to possess antimicrobial (Jalsenjak et al., 1987), anti-Alzheimer's (Akhondzadeh et al., 2003), antiviral (Mashahiro et al., 1994), antioxidant (Wang et al., 1998), neuroprotective (Imanshahidi M., 2006), hypoglycemic (Alarcon-Aguilar, 2002; Eidi, 2005), antimutagenic (Vujosević and Blagojević, 2004), antiinflammatory (Baricevic, 2001), hypotensive and central nervous system depressant (Newall et al., 1996) activities. The traditional water decoction (tea) of common Sage improves the liver anti-oxidant potential (Limaa et al., 2005).

There is no report available on its antidiarrheal or 
antispasmodic activity despite of its medicinal use in diarrhea and colic. This study reports the antidiarrheal and antispasmodic activities of the crude extract of $S$. officinalis, mediated possibly through voltage-dependent $\mathrm{K}^{+}$channel opening activity, which may explain the medicinal use of the plant in diarrhea and abdominal spasm.

\section{Materials and Methods}

\section{Plant material}

Aerial parts of $S$. officinalis were purchased from a local herbal store (Bin Menqash, Riyadh, Saudi Arabia) in March, 2011. The specimen was authenticated by Dr. Mohammed Yusuf, College of Pharmacy, King Saud University, Riyadh and the specimen has been preserved at the herbarium of the College of Pharmacy, King Saud University, Riyadh, Saudi Arabia and also at the Natural Product Research Unit, Department of Biological and Biomedical Sciences, Aga Khan University, Karachi, with voucher number So-AP-10-11-105.

\section{Preparation of crude extract}

The aerial parts of $S$. officinalis were soaked in the aqueous-methanol (30:70) for three days while shaking occasionally (Williamson et al., 1998) and filtered through muslin cloth and Whatman filter paper (Maidstone, UK) simultaneously. This procedure was repeated three times and all the filtrates were pooled and evaporated on a rotary evaporator (Model RE-111, Buchi, Flawil, Switzerland) under reduced pressure ($760 \mathrm{~mm} \mathrm{Hg}$ ) to obtain the crude extract, yielding approximately $15 \%$.

\section{Chemicals}

Acetylcholine perchlorate (ACh), glibenclamide (Gb), 4aminopyridine (4-AP), loperamide were purchased from Sigma Chemicals Company (USA). Chemicals used for making physiological salt solutions were: Potassium chloride (Sigma Co), calcium chloride, glucose, magnesium sulphate, potassium dihydrogen phosphate, sodium bicarbonate and sodium chloride (E. Merck, Darmstadt, Germany). All chemicals used were of the analytical grade available and solubilized in distilled water.

\section{Experimental animals}

Local breed rabbits (1-1.2 kg) and Balb-C mice (20-25 g) of either sex were kept at the Animal House of the Aga Khan University and maintained at $23-25^{\circ} \mathrm{C}$. Animals were given tap water ad libitum and a standard diet consisting of $(\mathrm{g} / \mathrm{kg})$ : Flour 380, fiber 380, molasses 12, $\mathrm{NaCl}$ 5.8, nutrivet L. 2.5, potassium metabisulfate 1.2, vegetable oil 38, fish meal 170 and powdered milk 150. Rabbits starved for 24 hours were sacrificed by blow on back of head and cervical dislocation. Experiments were performed in compliance with the rulings of the Institute of Laboratory Animal Resources, Commission on Life Sciences, National Research Council (NRC, 1996) and approved by the Ethical Committee of Research on Animals of the Aga Khan University.

\section{Castor oil-induced diarrhea}

Thirty Balb-C mice of either sex were randomly divided into four groups of five each and were housed individually in cages. All the animals had fasted for 24 hours before the start of the experiment. The first group received saline $(10 \mathrm{~mL} / \mathrm{kg})$ orally and acted as negative control. The second and third groups respectively received 100 and $300 \mathrm{mg} / \mathrm{kg}$ of the crude extract. The fourth group served as a positive control and received loperamide $(10 \mathrm{mg} / \mathrm{kg})$. After 1 hour, each animal received castor oil $(10 \mathrm{~mL} / \mathrm{kg}$, orally) through a feeding needle. After 6 hours of administration of castor oil, cages were observed for the presence of typical diarrheal droppings; the absence of diarrheal drops was noted as positive result, indicating protection from diarrhea (Jebunnessa et al., 2009; Shah et al., 2011).

\section{In vitro experiments}

Gut preparations (jejunum) from rabbit (Shah et al., 2011) were obtained after sacrificing the animals through cervical dislocation. The abdomen was cut open, required tissues were identified and isolated out and the required segments of jejunum of 2-3 cm length were mounted in $10 \mathrm{~mL}$ tissue baths containing the Tyrode's solution, maintained at $37^{\circ} \mathrm{C}$ and aerated with a mixture of $5 \%$ carbon dioxide and $95 \%$ oxygen (carbogen). The composition of Tyrode's solution (mM) was $\mathrm{KCl} 2.68, \mathrm{NaCl} 136.9, \mathrm{MgCl}_{2} 1.05, \mathrm{NaHCO}_{3}$ 11.90, $\mathrm{NaH}_{2} \mathrm{PO}_{4}$ 0.42, $\mathrm{CaCl}_{2}$ 1.8, and glucose 5.55 (pH 7.4). A preload of $1 \mathrm{~g}$ was applied to each tissue, and the contractile responses were recorded using isotonic transducer 50-6360 (Harvard Apparatus, Holliston, MA, USA) coupled with PowerLab (ML-845) data acquisition system (AD Instruments; Sydney, Australia) and a computer using chart software (version 5.3). The tissues were allowed to equilibrate for a period of 30 min, and then stabilized with a sub-maximal concentration of acetylcholine $(0.3 \mu \mathrm{M})$. The tissues were presumed stable only after the reproducibility of the said responses. The spasmolytic effect of the crude extract of $S$. officinalis was measured as the percent change in jejunum spontaneous contractions.

To assess the involvement of $\mathrm{K}^{+}$channel opening (Gilani et al., 2006) and $\mathrm{Ca}^{++}$antagonist-like mechanisms (Bashir et al., 2011), the spasmolytic effect of the plant extract was tested on low $\mathrm{K}^{+}(25 \mathrm{mM})$ and high $\mathrm{K}^{+}$ (80 $\mathrm{mM}$ )-induced contractions in the isolated rabbit jejunum preparations. Following a sustained contraction in response to $\mathrm{K}^{+}$, the test material was added in a 
cumulative fashion to obtain the concentration-dependent inhibitory responses. The relaxation of the tissue preparation was expressed as percentage of the control contraction mediated by the added spasmogen.

\section{Statistical analysis}

Data are expressed as mean \pm standard error of mean (SEM, $\mathrm{n}=$ number of experiment) and the median effective concentrations $\left(\mathrm{EC}_{50}\right)$ with $95 \%$ confidence intervals (CI). Chi-square $\left(c^{2}\right)$ test was applied to differentiate the results in antidiarrheal activity assay. A $p<0.05$ is considered to be statistically significant. Concentration response curves (CRCs) were analyzed by non-linear regression using GraphPad program (GraphPad, San Diego, CA, USA).

\section{Results}

The crude extract of $S$. officinalis exhibited a dosedependent (100-300 mg/kg) protective effect against castor oil-induced diarrhea in mice. The negative control group (saline treated) did not show any protection against castor oil-induced diarrhea as expected. Pretreatment of animals with the plant extract, showed 40 and $80 \%$ protection from diarrhea at the respective doses of 100 and $300 \mathrm{mg} / \mathrm{kg}$. Loperamide $(10 \mathrm{mg} / \mathrm{kg})$ showed complete protection from diarrhea $(\mathrm{p}<0.01$ versus saline group) in the positive control group (Table I).

\begin{tabular}{|c|c|c|}
\hline \multicolumn{3}{|c|}{ Table I } \\
\hline \multicolumn{3}{|c|}{$\begin{array}{l}\text { Antidiarrheal activity of S. officinalis crude } \\
\text { extract on castor oil -induced diarrhea in mice }\end{array}$} \\
\hline Treatment & $\begin{array}{c}\text { No. of mice } \\
\text { with diarrhea }\end{array}$ & $\%$ Protection \\
\hline $\begin{array}{l}\text { Saline }(10 \mathrm{~mL} / \mathrm{kg})+ \\
\text { castor oil }(10 \mathrm{~mL} / \mathrm{kg})\end{array}$ & $5 / 5$ & 0 \\
\hline $\begin{array}{l}\text { S. officinalis }(100 \mathrm{mg} / \mathrm{mL}) \\
+ \text { castor oil }(10 \mathrm{~mL} / \mathrm{kg})\end{array}$ & $3 a / 5$ & 40 \\
\hline $\begin{array}{l}\text { S. officinalis }(300 \mathrm{mg} / \mathrm{mL}) \\
+ \text { castor oil }(10 \mathrm{~mL} / \mathrm{kg})\end{array}$ & $1 \mathrm{a} / 5$ & 80 \\
\hline $\begin{array}{l}\text { Loperamide }(10 \mathrm{mg} / \mathrm{kg})+ \\
\text { castor oil }(10 \mathrm{~mL} / \mathrm{kg}) \\
\text { a }<0.05 \text { and } \mathrm{b} p<0.01 \mathrm{vs} \text {. saline } \\
\text { square })\end{array}$ & $\begin{array}{c}0 \mathrm{~b} / 5 \\
+ \text { castor oil-trea }\end{array}$ & d group (Chi- \\
\hline
\end{tabular}

The crude extract caused a concentration-dependent inhibition of the spontaneous contractions of rabbit jejunum at low doses with respective $\mathrm{EC}_{50}$ value of 0.4 $\mathrm{mg} / \mathrm{mL}(0.9-2.1,95 \% \mathrm{CI}, \mathrm{n}=4)$ as shown in Figure 1 . When tested against low $\mathrm{K}^{+}(25 \mathrm{mM})$ and high $\mathrm{K}^{+}(80$ $\mathrm{mM}$ )-induced contractions, the crude extract inhibited both types of contractions but was distinctly more potent against low $\mathrm{K}^{+}$with respective $\mathrm{EC}_{50}$ value of 0.12 $\mathrm{mg} / \mathrm{mL}(0.1-0.2 ; \mathrm{n}=4)$ compared to high $\mathrm{K}^{+}$-induced contractions, with $\mathrm{EC}_{50}$ values of $2.3 \mathrm{mg} / \mathrm{mL}(1.8-2.9, \mathrm{n}$ $=4$ ) as shown in Figure 2 .

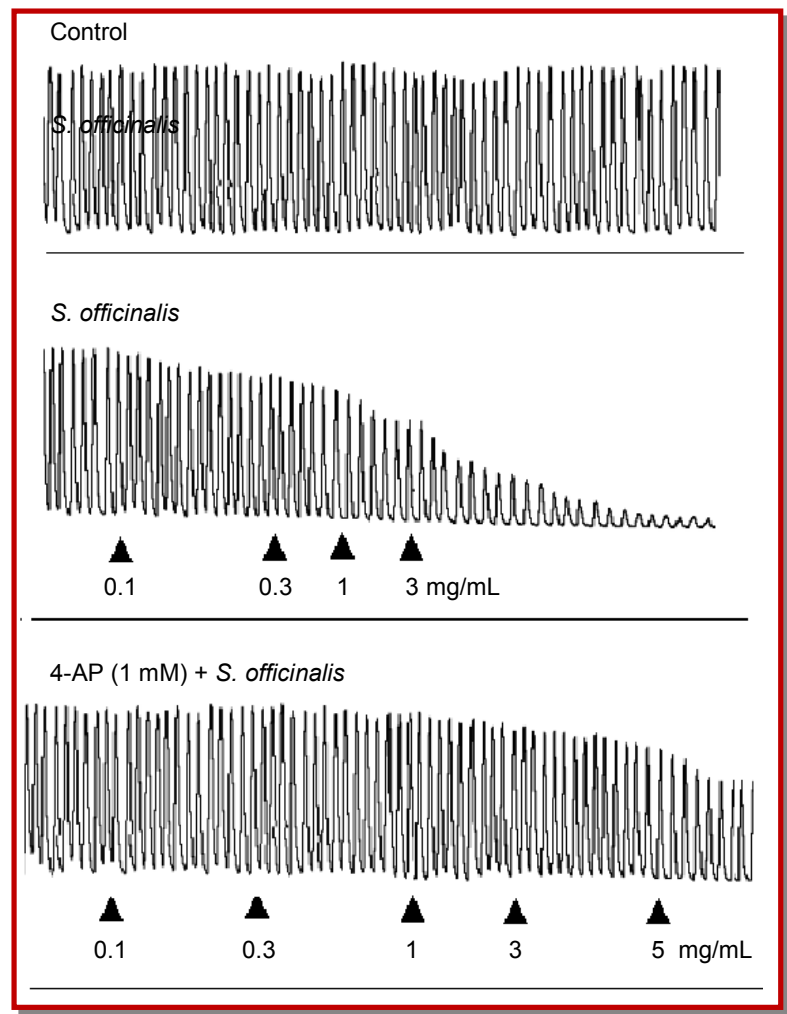

Figure 1: Tracing showing inhibitory effect of the crude extract of $S$. officinalis on spontaneous contractions in the absence and presence of $\mathrm{K}+$ channel blocker (4-AP)

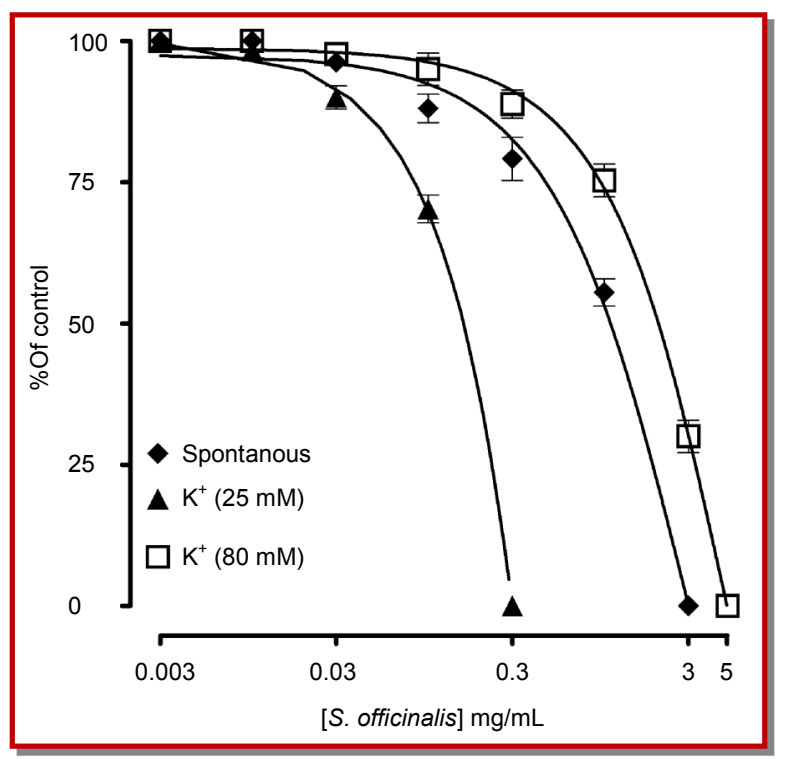

Figure 2: Inhibitory effect of the crude extract of S. officinalis crude extract, on spontaneous, low $\mathrm{K}^{+}(25 \mathrm{mM})$ and high $\mathrm{K}^{+}(80$ $\mathrm{mM})$-induced contractions in isolated rabbit jejunum preparations. Symbols represent mean \pm SEM; $n=4-5$

To assess the subtype of $\mathrm{K}^{+}$channels involved, the tissues were pretreated with two different $\mathrm{K}^{+}$channel antagonists. In the presence of 4-aminopyridine (4-AP, 


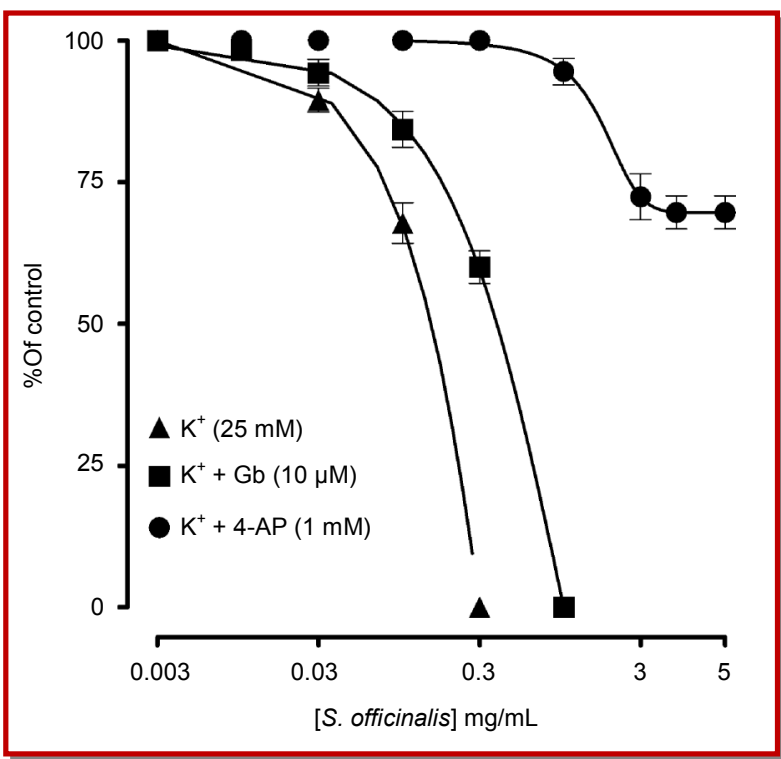

Figure 3: Inhibitory effect of the crude extract of S. officinalis, against low $\mathrm{K}^{+}$-induced contractions in the absence and presence of glibenclamide $(\mathrm{Gb})$, and 4-aminopyridine (4-AP) in isolated rabbit jejunum preparations. Symbols represent mean $\pm \mathrm{SEM} ; \mathrm{n}=4-5$

$1 \mathrm{mM})$, the inhibitory effect of the plant extract on low $\mathrm{K}^{+}$-induced contractions was markedly inhibited resulting in only $24.5 \pm 4.4 \%$ inhibition, observed at the maximum tested concentration of $10 \mathrm{mg} / \mathrm{mL}$, while the presence of glibenclamide $(10 \mu \mathrm{M})$ had negligible effect (Figure 3).

\section{Discussion}

Based on the medicinal use of Sage in diarrhea and abdominal spasm (Duke, 2002), the crude extract of Sage was tested for its antidiarrheal and antispasmodic activities using the in vivo and in vitro assays. Our study demonstrated that the crude extract provides protection against castor oil-induced diarrhea similar to loperamide. Castor oil increases intestinal fluid contents and causes diarrhea indirectly through ricinoleic acid formation, which changes the electrolytes and water transport and generates enormous contractions in transverse and distal colon (Iwao, 1962).

To investigate if the plant exhibits its antidiarrheal activity through inhibitory effect on gut motility, the plant extract was tested on the spontaneously contracting isolated rabbit jejunum preparations. It showed a dose-dependent inhibitory effect on spontaneous contractions, thus showing that the observed antidiarrheal effect of the plant extract appears to be mediated through the presence of some gut relaxant component(s) in it. In our earlier studies, we observed that the spasmolytic effect of medicinal plants is usually mediated through $\mathrm{K}^{+}$channel opening (Gilani et al.,
2005, 2006) or $\mathrm{Ca}^{++}$channel blockade (Bashir et al., 2011; Shah et al., 2011; Shah et al., 2011a). To assess, whether the spasmolytic effect of the crude extract of $S$. officinalis was also mediated via similar mechanism(s), it was tested on low $\mathrm{K}^{+}(25 \mathrm{mM})$ and high $\mathrm{K}^{+}(80 \mathrm{mM})$-induced contractions. Interestingly, the gut inhibitory effect of the plant extract against low $\mathrm{K}^{+}$-induced contractions was mediated at 10-30 times lower concentrations when compared with that obtained against spontaneous or high $\mathrm{K}^{+}$-induced contractions, indicative of $\mathrm{K}^{+}$channel opening activity (Gilani et al., 2005). A substance that selectively inhibits the contractions induced by low $\mathrm{K}^{+}$ $(<30 \mathrm{mM})$ is considered a $\mathrm{K}^{+}$channel opener, while $\mathrm{Ca}^{++}$ antagonists inhibit both low and high $\mathrm{K}^{+}$-induced contractions equally and these experiments allow us to distinguish $\mathrm{K}^{+}$channel opener from CCB (Hamilton et al., 1986; Kishii et al., 1992).

In order to assess the specific type of $\mathrm{K}^{+}$channels involved in the gut inhibitory effect, the effect of plant extract on low $\mathrm{K}^{+}$was reproduced in the presence of glibenclamide, a blocker of ATP-dependent $\mathrm{K}^{+}$channels (Frank et al., 1994) and 4-Aminopyridine, a voltage dependent $\mathrm{K}^{+}$channels blocker (Okabe et al., 1987). Glibenclamide was found to have negligible effect, while 4-AP almost completely inhibited the low $\mathrm{K}^{+}$induced contractions suggesting that the antispasmodic effect of the plant extract is preferentially mediated through activation of voltage-dependent $\mathrm{K}^{+}$channels (Kv channels). All gut smooth muscles studied express $\mathrm{Kv}$ channels. Typically, Kv channels are minimally activated at the resting membrane potential (RMP) but make a small but finite contribution to the overall resting $\mathrm{K}^{+}$conductance $(\mathrm{gK})$. $\mathrm{Kv}$ channels increase their probability of opening with membrane depolarization (Vogalis, 2000). These results indicate that the spasmolytic effect of the crude extract is mediated through combination of the dominant voltage sensitive $\mathrm{K}^{+}$ channels activation and weak $\mathrm{Ca}^{++}$antagonist mechanisms, which may be responsible for the antidiarrheal effect observed in the in vivo studies, though additional mechanism(s) cannot be ruled out. The presence of antimicrobial activity (Jalsenjak et al., 1987) is likely to play complementary role particularly in infectious diarrhea. $\mathrm{K}^{+}$channel openers are relatively new class of drugs that comprises of a diverse group of molecules with wide range of potential therapeutic uses, like gastrointestinal spasm, asthma, hypertension and urinary incontinence (Empfield et al., 1995; Mannhold, 2004). These compounds open $\mathrm{K}^{+}$channels and cause membrane hyperpolarization through the increase in $\mathrm{K}^{+}$ efflux, thus causing decrease in the intracellular free $\mathrm{Ca}^{++}$leading to smooth muscle relaxation (Cook, 1998; Quest, 1992; Lenz and Wagner, 1995).

In conclusion, these data suggest that the crude extract of $S$. officinalis possesses antidiarrheal and antispasmodic activities, mediated possibly through the 
activation of voltage sensitive $\mathrm{K}^{+}$channels together with weak $\mathrm{Ca}^{++}$antagonist effect. Therefore, this study provides sound pharmacological basis for the medicinal use of S. officinalis (Sage) in hyperactive gut disorders, such as abdominal colic and diarrhea.

\section{Acknowledgements}

This study was initiated during the visit of Prof. A. H. Gilani to the King Saud University as a part of Visiting Professor Program.

\section{References}

Akhondzadeh S, Noroozian M. Mohammadi M, Ohadinia S, Jamshidi AH, Khani M. Salvia officinalis extract in the treatment of patients with mild to moderate Alzheimer's disease: A double blind, randomized and placebo-controlled trial. J Clin Pharm Ther. 2003; 28: 53-59.

Alarcon-Aguilar, FJ, Roman-Ramos R, Flores-Saenz JL, Aguirre -Garcia F. Investigation on the hypoglycaemic effects of extracts of four Mexican medicinal plants in normal and alloxan-diabetic mice. Phytoth Res. 2002; 16: 383-86.

Baricevic D, Sosa S, Della Loggia R, Tubaro A, Simonovska B, Krasna A, et al. Topical anti-inflammatory activity of Salvia officinalis L. leaves: The relevance of ursolic acid. J Ethnopharmacol. 2001; 75: 125-32.

Bashir S, Memon R, Gilani AH. Antispasmodic and antidiarrheal activities of Valeriana hardwickii rhizome are putatively mediated through calcium channel blockade. Evid Based Compl Altern Med. 2011: 2011: 304960.

Cook NS. The pharmacology of potassium channels and their therapeutic potential. Trends Pharmacol Sci. 1988; 9; 21-28.

Duke JA, Bogenschutz-Godwin MJ, duCelliar J, Duke PAK. Handbook of medicinal herbs, 2nd ed. Boca Raton, CRC Press, 2002.

Eidi M, Eidi A, Zamanizadeh H. Effect of Salvia officinalis L. leaves on serum glucose and insulin in healthy and streptozotocin-induced diabetic rats. J Ethnopharmacol. 2005; 100: 310-13.

Empfield JR, Russell K, Trainor DA. Potassium channel openers: Therapeutic possibilities. Pharmaceutical News, 1995; 6: 23-27.

Fleming T. PDR for herbal medicines, 1st ed. Montvale, Medical Economics Company, 1998, p 1113.

Frank H, Puschmann A, Schusdziarra V, Allescher HD. Functional evidence for a glibenclamide-sensitive $\mathrm{K}^{+}$ channel in rat ileal smooth muscle. Eur J Pharmacol. 1994; 271: 379-86.

Gilani AH, Khan AU, Ghayur MN, Ali SF, Herzig JW. Antispasmodic effects of Rooibos tea (Aspalathus linearis) is mediated predominantly through $\mathrm{K}^{+}$-channel activation. Basic Clin Pharmacol Toxicol. 2006; 99: 365-73.

Gilani AH, Khan AU, Jabeen Q, Subhan F, Ghafar G.
Antispasmodic and blood pressure lowering effects of Valeriana wallichii are mediated through $\mathrm{K}^{+}$channel activation. J Ethnopharmacol. 2005; 100: 347-52.

Hamilton TC, Weir SW, Weston TH. Comparison of the effect of BRL34915 and verapamil on electrical and mechanical activity in rat portal vein. Bri J Pharmacol. 1986; 88: 103-11.

Imanshahidi $\mathrm{M}$, Hosseinzadeh $\mathrm{H}$. The pharmacological effects of Salvia species on the central nervous system. Phytother Res. 2006; 20: 427-37

Iwao I, Terada Y. On the mechanism of diarrhea due to castor oil. Jap J Pharmacol. 1962; 12: 137-45.

Jalsenjak V, Peljnajk S, Kustrak D. Microcapsules of sage oil, essential oils content and antimicrobial activity. Pharmazie. 1987; 42: 419-20.

Jebunnessa, Uddin SB, Mahbub-Uz-Zaman M, Akhtar R, Ahmed NU. Antidiarrheal activity of ethanolic bark extract of Mitragyna diversifolia. Bangl J Pharmacol. 2009; 4: 144-46.

Kishii KI, Morimoto T, Nakajima N, Yamazaki K, Tsujitani M, Takayanagi I. Effect of LP-805, a novel vasorelaxant agent, a potassium channel opener on rat thoracic aorta. Gen Pharmacol. 1992; 23: 347-53.

Lenz T, Wagner G. Potential role of potassium channel openers for the treatment of cardiovascular disease. In: Hypertension: Pathophysiology, diagnosis and management. Laragh JH, Brenner BM (eds). New York, Raven Press, 1995, pp 2953-68.

Limaa CF, Andradeb PB, Seabrab RM, Fernandes-Ferreiraa M, Pereira-Wilson C, The drinking of a Salvia officinalis infusion improves liver anti-oxidant status in mice and rats. J Ethnopharmacol. 2005; 97: 383-89.

Lu Y,Foo LY. Salvianolic acid L, a potent phenolic anti-oxidant from Salvia officinalis. Tetrahedron Lett. 2001; 42: 8223-25.

Mannhold R. K $\mathrm{K}_{\text {ATP }}$ channel openers: Structure-activity relationships and therapeutic potential. Med Res Rev. 2004; 24; 213-66.

National Research Council, Guide for the Care and Use of Laboratory Animals. Washington, National Academy Press, 1996, pp 1-5.

Newall C, Anderson LA, Phillipson JD. In: Herbal medicines: A guide for health-care professionals. Newall CA, Anderson LA, Phillipson JD (eds). The Pharmaceutical Press, London, 1996.

Okabe K, Kitamura K, Kuriyama H. Feature of 4aminopyridine sensitive outward current observed in single smooth muscle cells from the rabbit pulmonary artery. Pfluegers Arch. 1987; 409: 561-68.

Qnais EY, Abu-Dieyeh M, Abdulla FA, Abdalla SS. The antinociceptive and anti-inflammatory effects of Salvia officinalis leaf aqueous and butanol extracts. Pharm Biol. 2010; 48: 1149-56.

Quest U. Potassium channel openers: Pharmacological and clinical aspects. Fund Clin Pharmacol. 1992; 6: 279-93.

Shah AJ, Zaidi MA, Hamidullah SH, Gilani AH. Antidiarrheal and antispasmodic activities of Vincetoxicum stocksii are 
mediated through calcium channel blockade. Bangladesh J Pharmacol. 2011; 6: 46-50.

Shah AJ, Begum S, Hassan SI, Ali SN, Siddiqui BS, Gilani AH. Pharmacological basis for the medicinal use of Psidium guajava leave in hyperactive gut disorders Bangladesh J Pharmacol. 2011; 6: 100-105.

Tada M, Okuno K, Chiba K, Ohnishi E, Yoshii T. Antiviral diterpenes from Salvia officinalis. Phytochem. 1994; 35: 539 -41 .

Vogalis F. Potassium channels in gastrointestinal smooth muscle. J Auton Pharmacol. 2000; 20: 207-19.

Vujosević M, Blagojević J. Antimutagenic effects of extracts from sage (Salvia officinalis) in mammalian system in vivo. Acta Vet Hung. 2004; 52: 439-43.

Wang M, Li J, Rangarajan M, Shao Y, LaVoie EJ, Hang T-Ch, Ho Ch-T. Anti-oxidative phenolic compounds from sage (Salvia officinalis). J Agri Food Chem. 1998; 46: 4869-73.

Williamson EM, Okpako DT, Evans FJ. Selection, preparation and pharmacological evaluation of plant material. Chichester, John Wiley \& Sons, 1998, pp 15-23. 